\title{
FORMULASI HARD CANDY MENGGUNAKAN PEWARNA ALAMI FIKOSIANIN Spirulina platensis
}

\section{Hard Candy Formulation using Phycocyanin of Spirulina platensis as Natural Colorant \\ DF Andini1a, Mardiah'1, M Kawaroe ${ }^{2}$}

${ }^{1}$ Jurusan Teknologi Pangan dan Gizi, Fakultas Ilmu Pangan Halal, Universitas Djuanda Bogor, Jl. Tol Ciawi No.1, Kotak Pos 35 Ciawi, Bogor 16720

${ }^{2}$ Fakultas Perikanan dan Ilmu Kelautan, Institut Pertanian Bogor

aKorespondensi: Devita Febry Andini, E-mail: dfebry01@gmail.com

(Diterima oleh Dewan Redaksi: 01-09-2017)

(Dipublikasikan oleh Dewan Redaksi: 25-10-2017)

\begin{abstract}
This research conducted formulations of Hard Candy with the addition of blue biopigment phycocyanin Spirulina platensis extract as a natural colorant and studied the stability of phycocyanin color after applied to food product. The first phase of the study was phycocyanin extraction used freezing method and encapsulation of phycocyanin used maltodextrin with the ratio 1:1. The second phase was Hard Candy processing with two experimental factors in the form of sucrose formula variation $(80 \mathrm{~g}$ and $100 \mathrm{~g}$ ) and phycocyanin concentration variation $(1 \mathrm{~g}, 2 \mathrm{~g}$, and $3 \mathrm{~g})$. The third phase was conducted product analysis. The experimental design that was used is Completely Random Design (CRD) Two Factors. Hard Candy products were tested by hedonic (preference) against the parameters of color, taste, and texture (used 25 semi-trained panelists). The selected formula according to panelists was $80 \mathrm{~g}$ of sucrose and $3 \mathrm{~g}$ of phycocyanin Hard Candy with the hedonic test results i.e. color was prefered, taste and texture were rather preferred. The chemical analysis showed that the antioxidant activity $\left(\mathrm{IC}_{50}\right)$ value, reducing sugar, saccharose, water, ash and protein content are 319,06 ppm, 16,92\%, 44,33\%, 0,92\%, 0,02\%, and 72,33 ppm respectively. The blue color on Hard Candy remained stable for 28 days of observation.
\end{abstract}

Keywords: blue biopigment, phycocyanin, Spirulina platensis, hard candy

\section{ABSTRAK}

Penelitian ini mencari formulasi Hard Candy dengan penambahan ekstrak biopigmen biru fikosianin Spirulina platensis sebagai pewarna alami dan mempelajari kestabilan warna fikosianin setelah diaplikasikan ke dalam produk pangan. Penelitian tahap satu yaitu ekstraksi fikosianin menggunakan metode pembekuan dan enkapsulasi fikosianin menggunakan maltodekstrin dengan perbandingan 1:1. Penelitian tahap dua yaitu pengolahan Hard Candy dengan dua faktor percobaan berupa variasi formula sukrosa $80 \mathrm{~g}$ dan $100 \mathrm{~g}$ dan variasi konsentrasi fikosianin $1 \mathrm{~g}, 2 \mathrm{~g}$, dan $3 \mathrm{~g}$. Pada penelitian tahap tiga dilakukan analisis produk. Rancangan percobaan yang digunakan yaitu Rancang Acak Lengkap (RAL) Dua Faktor. Produk Hard Candy diuji hedonik dengan parameter mutu yaitu warna, rasa, dan tekstur (menggunakan 25 panelis semi terlatih). Formula Hard Candy terpilih menurut panelis yaitu Hard Candy dengan kandungan sukrosa $80 \mathrm{~g}$ dan fikosianin 3 g dengan hasil uji hedonik yaitu warna disukai, rasa dan tekstur agak disukai. Hasil analisis kimia menunjukkan nilai aktivitas antioksidan $\left(\mathrm{IC}_{50}\right)$ pada produk Hard Candy sebesar 319,05 ppm, kadar gula reduksi 16,92\%, kadar sakarosa 44,33\%, kadar air 0,92\%, kadar abu 0,02\%, dan kadar protein 72,33 ppm. Warna biru Hard Candy tetap stabil selama 28 hari pengamatan.

Kata Kunci: biopigmen biru, fikosianin, Spirulina platensis, permen keras

Andini DF, Mardiah, M Kawaroe. 2017. Formulasi Hard Candy menggunakan Pewarna Alami Fikosianin Spirulina platensis. Jurnal Agroindustri Halal 3(2): 117-125 


\section{PENDAHULUAN}

Warna adalah sebuah estetika yang penting dalam membentuk sebuah penampilan produk pangan. Zat pewarna merupakan bahan tambahan pangan yang dapat memperbaiki penampilan makanan. Penambahan bahan pewarna makanan mempunyai beberapa tujuan, di antaranya adalah memberi kesan menarik bagi konsumen, menyeragamkan dan menstabilkan warna, serta menutupi perubahan warna akibat proses pengolahan dan penyimpanan. Zat pewarna makanan terbagi menjadi tiga bagian yaitu pewarna alami, pewarna identik alami, dan pewarna sintetis (Mudjajanto, 2006).

Penggunaan bahan pewarna kimia sintetis merupakan bahan pewarna yang biasa digunakan hampir di setiap produk pangan baik makanan atau minuman. Pada umumnya pewarna sintetis lebih sering digunakan dalam industri pangan karena lebih murah, ketersediaan banyak, lebih stabil, dan tahan lebih lama walaupun memiliki tingkat keamanan pangan yang lebih rendah. Di Indonesia, peraturan mengenai penggunaan zat pewarna yang diizinkan dan dilarang untuk pangan diatur melalui SK Menteri Kesehatan RI Nomor 722/Menkes/Per/IX/88 tentang bahan tambahan pangan.

Pemberitaan mengenai bahaya atau efek negatif pewarna sintetis meningkatkan kesadaran masyarakat untuk kembali menggunakan produk pewarna alami. Saat ini pewarna alami pada umumnya berbahan dasar tumbuhan tingkat tinggi seperti daun pandan, daun suji, kunyit dan hanya dimanfaatkan secara tradisional. Secara komersial, keberadaan pewarna alami kalah bersaing dengan pewarna sintetis yang banyak dijual di pasaran (Sedjati et al. 2012). Meskipun penggunaan pewarna alami relatif aman dikonsumsi dalam jangka panjang, pewarna alami memiliki beberapa keterbatasan dibandingkan dengan perwarna sintetik. Keterbatasan pewarna alami adalah seringkali memberikan rasa dan flavor khas yang tidak diinginkan, konsentrasi pigmen rendah, stabilitas pigmen rendah, keseragaman warna kurang baik dan spektrum warna tidak seluas pewarna sintetik.

Ekstrak biopigmen biru fikosianin dari Spirulina platensis pada penelitian ini akan diaplikasikan sebagai pewarna alami Hard Candy yang dapat diterima secara sensori dengan pengembangan sendiri dari bahan baku, formula atau racikan yang relatif sehat dan aman untuk dikonsumsi. Hard candy berwarna biru sudah cukup banyak ditemukan di pasaran, pewarna yang digunakan umumnya yaitu pewarna sintetik Brilliant blue. Penggunaan pewarna sintetik tersebut dalam jangka panjang dikhawatirkan dapat berdampak buruk bagi kesehatan manusia.

US-FDA memberikan pernyataan bahwa terdapat beberapa efek samping bagi kesehatan dari pewarna kimia sintetis biru Brilliant blue yaitu dapat menyebabkan penyakit kulit kebirubiruan, penyakit urine dan fases, serta hipotensi dan kematian (Liputan6, 2013). Oleh karena itu, dengan menggunakan fikosianin sebagai pewarna alami Hard Candy, diharapkan dapat menggantikan peran Briliant blue yang sudah dinilai tidak aman untuk kesehatan jangka panjang. Selain itu fikosianin juga mempunyai efek fungsional terhadap kesehatan tubuh.

Mikroalga merupakan sumber yang potensial dijadikan pewarna alami. Chlorella dan Spirulina merupakan salah satu jenis mikroalga yang dimanfaatkan sebagai suplemen makanan serta diketahui memiliki kandungan bahan yang bermanfaat untuk kesehatan (Kawaroe, 2015). Spirulina platensis menghasilkan pigmen bewarna hijau kebiru-biruan. Jenis pigmen yang terkandung dalam mikroalga tersebut yaitu fikosianin, klorofil-a, dan 
karotenoid yang dipercaya sebagai antioksidan tinggi dan agen anti-kanker (Pirenantyo et al. 2008).

\section{MATERI DAN METODE}

\section{Bahan dan Alat}

Bahan-bahan yang digunakan dalam penelitian adalah biomassa kering Spirulina platensis, air suling, kertas saring berabu, sukrosa, sirup glukosa, perasa mint, DPPH (1,1-diphenyl-2-picryl hydrazyl), metanol p.a., pereaksi Comassie Brilliant Blue (CBB), pereaksi Bovine Serum Albumin (BSA), Pb-asetat $1 / 2$ basa, $\left(\mathrm{NH}_{4}\right)_{2} \mathrm{HPO}_{4} 10 \%$, luff schoorl, KI $20 \%$, plate, tanur, pipet serologi $5 \mathrm{~mL}$, erlenmeyer $500 \mathrm{~mL}$, pendingin tegak, stop watch, pipet volumetrik $50 \mathrm{~mL}$, gelas ukur $50 \mathrm{~mL}$, termometer, batu didih, dan vortex.

\section{Prosedur}

Penelitian dibagi menjadi tiga tahap yaitu:

1. Tahap preparasi meliputi tahap pengadaan sampel biomassa kering Spirulina platensis, proses ekstraksi fikosianin, dan proses enkapsulasi fikosianin. Metode ekstraksi fikosianin dari Spirulina platensis dalam penelitian ini merupakan metode freezing dari

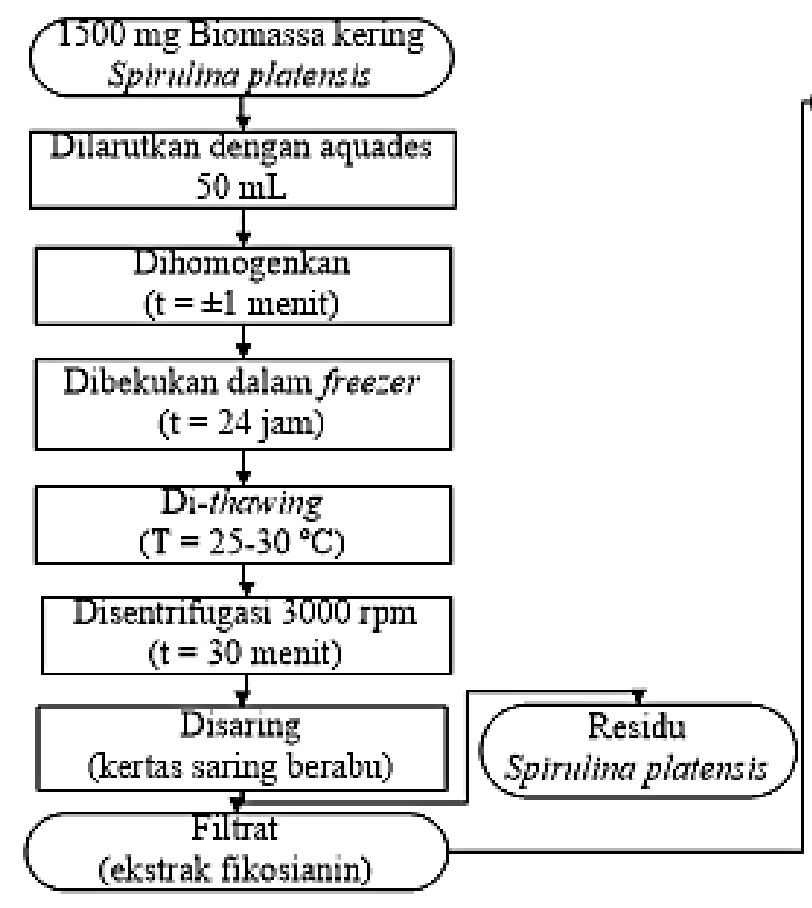

(A)

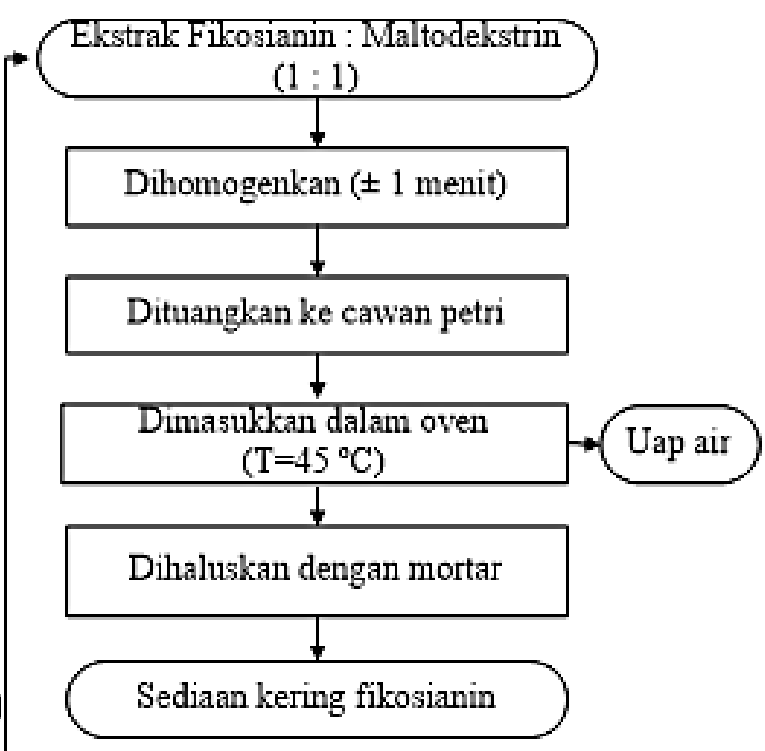

(B)

Gambar 1. (A) Diagram Alir Proses Ekstraksi Fikosianin (Hidayatulloh, 2016);

(B) Diagram Alir Proses Enkapsulasi FIkosianin (Modifikasi dari Lazuardi, 2014)

$\mathrm{H}_{2} \mathrm{SO}_{4} 25 \%, \mathrm{Na}_{2} \mathrm{~S}_{2} \mathrm{O}_{3} \quad 0,1 \mathrm{~N}$, indikator kanji $0,5 \%, \mathrm{HCl} 25 \%$, dan indikator PP. Alat yang digunakan adalah neraca analitik, neraca kasar, spatula/sudip, corong, freezer, sentrifuse, piala gelas $100 \mathrm{~mL}$ dan $500 \mathrm{~mL}$, labu semprot, pipet tetes, spektrofotometer UV Merk Hitachi U-2900, kuvet, labu ukur $100 \mathrm{ml}$ dan $250 \mathrm{ml}$, tabung reaksi, rak tabung reaksi, cawan, desikator, oven, bunsen, penangas air, hot
Hidayatulloh (2016). Ekstrak fikosianin yang diperoleh kemudian dienkapsulasi dengan menggunakan modifikasi metode dari Lazuardi (2014). Metode enkapsulasi yang digunakan yaitu dengan mencampurkan antara ekstrak fikosianin dengan maltodekstrin (1:1).

2. Tahap pengolahan permen keras dengan dua faktor percobaan berupa variasi formula sukrosa (F) yaitu $80 \mathrm{~g}$ 
(F1) dan 100 g (F2) dan variasi konsentrasi ekstrak fikosianin (B) yaitu $1 \mathrm{~g}$ (B1), 2 g (B2), dan $3 \mathrm{~g}$ (B3). Berikut tabel formulasi permen keras:

Tabel 1. Formulasi Permen Keras

\begin{tabular}{lcccccc}
\hline & \multicolumn{5}{c}{$\begin{array}{c}\text { Formulasi Permen Keras } \\
\text { (gram) }\end{array}$} \\
\cline { 2 - 7 } Bahan & \multicolumn{5}{c}{ F1 } & \multicolumn{4}{c}{ F2 } \\
\cline { 2 - 7 } & B1 & B2 & B3 & B1 & B2 & B3 \\
\hline Sukrosa & 80 & 80 & 80 & 100 & 100 & 100 \\
$\begin{array}{l}\text { Sirup } \\
\text { glukosa }\end{array}$ & 45 & 45 & 45 & 50 & 50 & 50 \\
Air & 100 & 100 & 100 & 100 & 100 & 100 \\
$\begin{array}{l}\text { Perisa } \\
\text { mint }\end{array}$ & 2,25 & 2,25 & 2,25 & 2,5 & 2,5 & 2,5 \\
$\begin{array}{l}\text { (1\%) } \\
\begin{array}{l}\text { Ekstrak } \\
\text { fikosia- } \\
\text { nin }\end{array}\end{array}$ & 1 & 2 & 3 & 1 & 2 & 3 \\
\hline
\end{tabular}

hedonik kemudian dianalisis kimia yaitu aktivitas antioksidan, kadar gula reduksi, kadar sakarosa, kadar air, kadar abu, dan kadar protein, dan stabilitas warna (28 hari).

\section{HASIL DAN PEMBAHASAN}

\section{Penelitian Tahap Preparasi}

Pada tahap ini dilakukan preparasi biopigmen biru fikosianin Spirulina platensis yang akan digunakan dalam pengolahan Hard Candy. Tahap preparasi meliputi tahap pengadaan sampel biomassa kering Spirulina platensis, proses ekstraksi fikosianin, dan proses enkapsulasi fikosianin. Metode dalam mendapatkan ekstrak fikosianin dari Spirulina platensis dalam penelitian ini merupakan metode dari Hidayatulloh

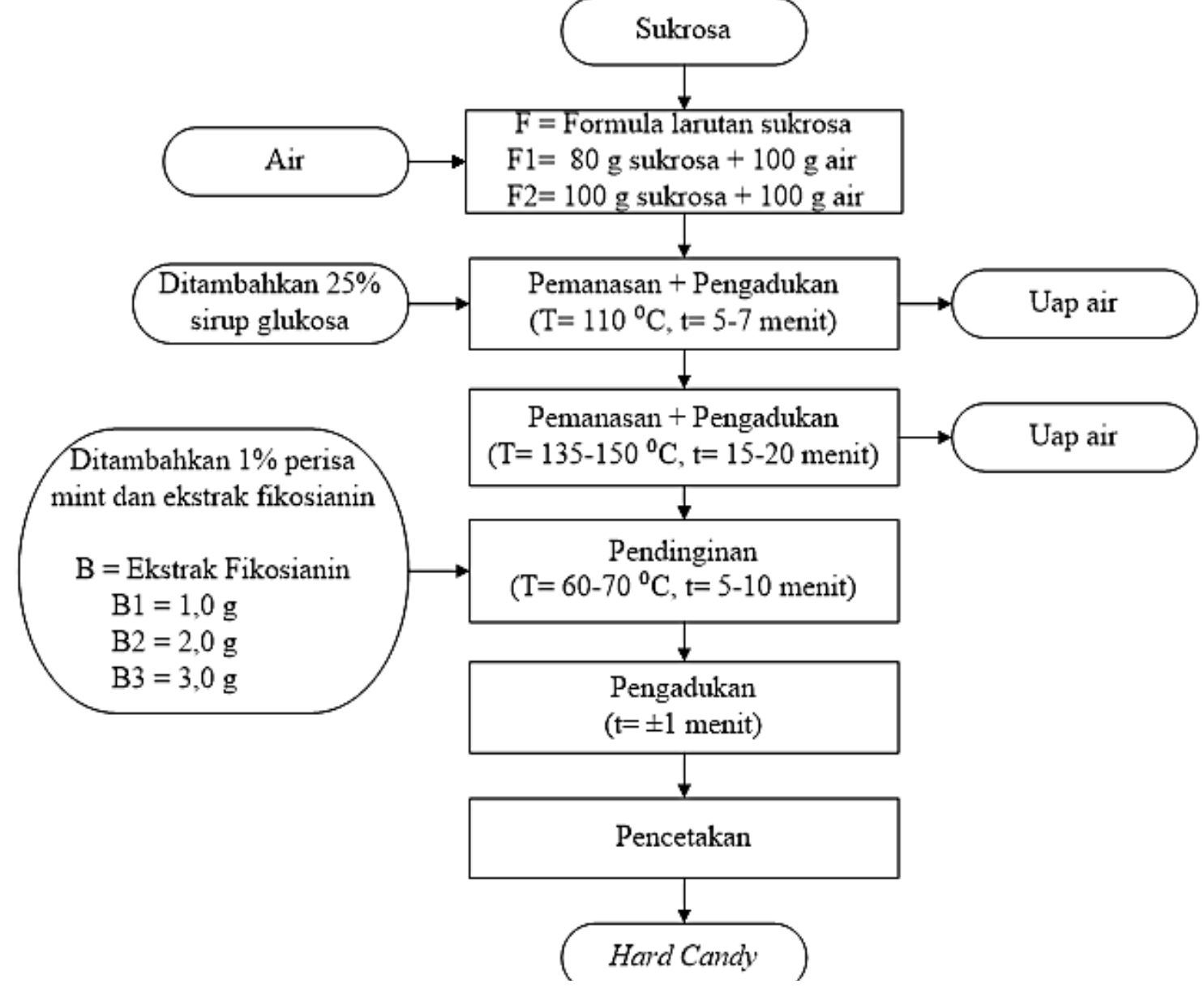

Sukrosa 
Metode ekstraksi fikosianin yang digunakan berdasarkan penelitian Hidayatulloh (2016) yaitu metode pembekuan atau freezing. Metode ekstraksi dengan pembekuan dipilih dikarenakan menghasilkan rata-rata yield fikosianin paling tinggi dibandingkan dengan metode maserasi dan Ultrasound Assisted Extraction (UAE) yaitu sebesar 26,53\%. Ekstrak fikosianin yang diperoleh kemudian dienkapsulasi dengan modifikasi metode dari Lazuardi (2014) dengan mencampurkan antara ekstrak fikosianin dengan maltodekstrin (1:1) kemudian dituangkan pada loyang dan dimasukkan pada oven pada suhu $45{ }^{\circ} \mathrm{C}$ hingga kering atau tidak gempal kemudian dihancurkan dengan penumbuk hingga menjadi bubuk. Maltodekstrin dipilih sebagai penyalut karena memiliki sifat dispersi yang cepat, daya larut yang tinggi maupun membentuk film, membentuk sifat higroskopis yang rendah, mampu membentuk body, sifat browning yang rendah, mampu menghambat kristalisasi dan memiliki daya ikat yang kuat (Srihari et al, 2010).

\section{Penelitian Tahap Pengolahan}

Pengolahan Hard

menggunakan faktor variasi formula larutan sukrosa (2 taraf: $80 \mathrm{~g}$ dan $100 \mathrm{~g}$ ) dan variasi penambahan ekstrak fikosianin (3 taraf: $1 \mathrm{~g}, 2 \mathrm{~g}$, dan $3 \mathrm{~g}$ ) dengan ulangan sebanyak dua kali. Larutan sukrosa dipanaskan hingga $110^{\circ} \mathrm{C}$ selama 5-7 menit lalu ditambahkan 25\% sirup glukosa dan dipanaskan hingga suhu $135-150 \quad{ }^{\circ} \mathrm{C}$ selama $15-20$ menit. Diturunkan suhu formula hingga $60-70{ }^{\circ} \mathrm{C}$ lalu ditambahan $1 \%$ perisa mint dan ekstrak fikosianin. Formula Hard Candy kemudian dicetak dan didinginkan hingga mengeras.

\section{Uji Hedonik}

Uji hedonik dilakukan untuk menentukan formula terpilih dan untuk melihat ada tidaknya pengaruh interaksi antara faktor variasi formula sukrosa dan variasi konsentrasi ekstrak fikosianin terhadap parameter mutu pengujian yaitu warna, rasa, dan tekstur. Skala penilaian hedonik yang digunakan yaitu 1-7 (1 = sangat tidak suka, $2=$ tidak suka, $3=$ agak tidak suka, $4=$ biasa, $5=$ agak suka, $6=$ suka, 7 = sangat suka). Pengujian hedonik dilakukan oleh 25 orang panelis semi terlatih sebanyak dua kali ulangan. Nilai rata-rata kesukaan panelis terhadap warna, rasa, dan tekstur Hard Candy dapat dilihat pada Tabel 2 .

Tabel 2. Nilai Rata-Rata Kesukaan Panelis terhadap Warna, Rasa, dan Tekstur Hard Candy

\begin{tabular}{cccc}
\hline \multirow{2}{*}{ Perlakuan } & \multicolumn{3}{c}{ Rata-Rata Nilai Hedonik } \\
\cline { 2 - 4 } & Warna & Rasa & Tekstur \\
\hline F1B1 & $3,52^{\text {d }}$ & $5,32^{\mathrm{a}}$ & $4.76^{\mathrm{a}}$ \\
F1B2 & $5,38^{\mathrm{b}}$ & $5,32^{\mathrm{a}}$ & $4.98^{\mathrm{a}}$ \\
F1B3 & $\mathbf{6 , 1 6}^{\mathrm{a}}$ & $\mathbf{5 , 4 4}^{\mathrm{a}}$ & $\mathbf{5 . 0 4}^{\mathrm{a}}$ \\
F2B1 & $4,22^{\mathrm{c}}$ & $5,36^{\mathrm{a}}$ & $4.66^{\mathrm{a}}$ \\
F2B2 & $5,48^{\mathrm{b}}$ & $5,34^{\mathrm{a}}$ & $4.60^{\mathrm{a}}$ \\
\hline
\end{tabular}

Ket: B=Variasi Penambahan Ekstrak Fikosianin; F=Variasi Formula Larutan Sukrosa. Notasi huruf yang berbeda pada tabel menunjukkan berbeda nyata pada tingkat kepercayaan $95 \%(\alpha=0.05)$.

Hasil uji ANOVA pada parameter warna menunjukkan bahwa perbedaan formula larutan sukrosa tidak berbeda nyata $(p>0,05)$ pada tingkat kesukaan panelis dan berbeda nyata $(\mathrm{p}<0,05)$ pada penambahan ekstrak fikosianin. Hasil uji lanjut DMRT parameter warna menunjukkan bahwa perlakuan B1, B2, dan B3 berbeda nyata dan interaksi antara larutan sukrosa dengan ekstrak fikosianin formula F1B3 berbeda nyata (paling berpengaruh) di antara perlakuan yang lainnya. Panelis lebih menyukai permen dengan warna biru yang lebih pekat.

Hasil uji ANOVA parameter rasa dan tekstur menunjukkan bahwa perbedaan formula larutan sukrosa dan ekstrak fikosianin tidak berbeda nyata $(p>0,05)$ pada tingkat kesukaan panelis. Formula terpilih berdasarkan nilai rataan tertinggi uji hedonik pada parameter warna, rasa, dan tekstur yaitu formula F1B3 (80 gram 
sukrosa +100 gram air +3 gram ekstrak fikosianin).

\section{Analisis Kimia Formula Terpilih}

Formula terpilih (F1B3) berdasarkan hasil uji hedonik selanjutnya dianalisis kimia mencakup analisis aktivitas antioksidan, kadar gula reduksi, kadar sakarosa, kadar air, kadar abu, dan kadar protein. Berikut merupakan hasil analisis kimia Hard Candy:

Tabel 3. Hasil Analisis Kimia Formula Terpilih Hard Candy

\begin{tabular}{clcc}
\hline No & Analisis & Hasil & $\begin{array}{c}\text { Standar } \\
\text { (SNI Hard } \\
\text { Candy*) }\end{array}$ \\
\hline 1 & $\begin{array}{l}\text { Aktivitas } \\
\text { antioksidan }\end{array}$ & $\begin{array}{c}319,06 \\
\text { ppm }\end{array}$ & - \\
2 & Gula & $16,92 \%$ & Maks.22\% \\
& reduksi & & \\
3 & Sakarosa & $44,33 \%$ & Min. 40\% \\
4 & Kadar air & $0,92 \%$ & Maks.3,5\% \\
5 & Kadar abu & $0,02 \%$ & Maks.2,0\% \\
6 & Kadar & 72,33 & - \\
& protein & ppm & \\
\hline
\end{tabular}

Ket: *SNI Hard Candy No. 3547.1:2008

\section{Aktivitas Antioksidan}

Senyawa aktif pada Spirulina yang dapat digunakan sebagai sumber antioksidan di antaranya adalah fikosianin, betakaroten, tokoferol, $\gamma$ linoleic acid dan komponen fenol (Merdekawati et al., 2009). Nilai IC 50 (Inhibition Concentration) merupakan besarnya konsentrasi yang dapat menghambat akitivitas radikal bebas sebanyak $50 \%$. Semakin rendah nilai $\mathrm{IC}_{50}$ yang terukur maka semakin tinggi aktivitas antioksidannya. Suatu aktivitas antioksidan dikatakan sangat kuat bila nilai $\mathrm{IC}_{50}$ kurang dari $50 \mathrm{ppm}$ dan lemah bila nilai $\mathrm{IC}_{50}$ lebih dari 200 ppm (Molyneux, 2004).

Pada hasil pengujian aktivitas antioksidan diperoleh nilai $\mathrm{IC}_{50}$ yaitu 319,06 ppm. Berdasarkan hasil pengujian dapat disimpulkan bahwa aktivitas antioksidan dalam Hard Candy bersifat lemah, hal ini dapat disebabkan karena terdapat proses pengeringan pada bahan baku fikosianin saat proses enkapsulasi dan suhu tinggi saat pengolahan Hard Candy. Penelitian Hartanti dan Sri (2009) menunjukkan bahwa perbedaan perlakuan preparasi bahan baku berpengaruh terhadap aktivitas antioksidan. Pada bahan baku yang mengalami proses pengeringan, aktivitas antioksidan yang dihasilkan lebih kecil, hal ini disebabkan karena terjadinya degradasi atau kerusakan selama proses pengeringan. Beberapa senyawa antioksidan mengalami kerusakan sehingga aktivitas antioksidannya turun. Apriandji (2008) juga menyatakan bahwa antioksidan kuat akan rusak oleh panas dan pemasakan.

\section{Kadar Gula Reduksi}

Dalam pembuatan permen dilakukan pemanasan sukrosa dan air yang menyebabkan sukrosa terhidrolisis menjadi glukosa dan fruktosa yang disebut juga sebalai gula pereduksi. Kandungan gula pereduksi merupakan salah satu parameter mutu permen. Sukrosa tidak termasuk sebagai gula pereduksi, sedangkan glukosa yang digunakan dalam pembuatan Hard Candy maupun hasil inversi dari sukrosa merupakan gula pereduksi. Menurut Winarno (2004), jika sukrosa yang dilarutkan dalam air dipanaskan, maka sebagian sukrosa akan terurai menjadi glukosa dan fruktosa yang disebut juga sebagai gula invert. Glukosa dan sukrosa mampu menjadi bahan pembawa atau menyebabkan terjadinya proses reduksi atau pengambilan oksigen.

Kadar gula pereduksi formula Hard Candy terpilih adalah 16,92\%. Nilai kadar gula pereduksi yang disyaratkan dalam SNI Hard Candy No. 3547.1:2008 maksimal 22\%. Tingkat gula pereduksi dapat dipengaruhi oleh perbandingan sukrosan dan sirup glukosa dan proses inversi gula. Apabila kadar gula pereduksi lebih dari $22 \%$ dapat menyebabkan stickness atau graining. 


\section{Kadar Sakarosa}

Selain sirup glukosa dan flavor, sukrosa atau sakarosa merupakan salah satu bahan dasar permen yang sangat penting. Sakarosa dalam pembuatan permen sangat menentukan kandungan sukrosa yang dihasilkan. Kadar sakarosa yang dihasilkan dari produk terpilih adalah 44,33\%. Nilai kadar gula pereduksi yang disyaratkan dalam SNI Hard Candy No. 3547.1:2008 minimal 40\%.

Secara umum dengan semakin menurunnya sukrosa yang digunakan maka kandungan sakarosa semakin rendah. Semakin tinggi kadar sakarosa maka kadar gula pereduksi semakin rendah, hal ini terjadi karena tidak seluruh sukrosa terinversi menjadi glukosa dan fruktosa, namun masih ada sebagian yang berada dalam bentuk sukrosa sehingga mempengaruhi kadar sakarosa sampel.

\section{Kadar Air}

Kadar air merupakan salah satu parameter yang sangat menentukan mutu Hard Candy. Semakin rendah kadar air yang dihasilkan maka daya tahan dan masa penyimpanan semakin lama. Kandungan air yang dihasilkan dari produk terpilih dalam penelitian ini adalah 0,92\%. Nilai kadar air yang disyaratkan dalam SNI adalah maksimal 3,5\%. Dengan melihat data terpilih hasil penelitian, perlakuan F1B3 (formula sukrosa 80 gram + air 100 gram + fikosianin 3 gram) memenuhi syarat SNI. Kadar air yang cukup rendah ini diduga selain disebabkan karena faktor bahan baku yang digunakan juga sangat dipengaruhi oleh suhu pemasakan. Menurut Purnomo dan Adiono (1985), seni membuat permen dengan daya tahan memuaskan terletak pada pembuatan produk dengan kadar air minimum. Penggunaan suhu $150{ }^{\circ} \mathrm{C}$ diduga cukup tepat untuk menghasilkan Hard Candy dengan kadar air yang cukup rendah seperti pada hasil penelitian ini, menurut Alikonis (1979) pada temperatur 154,4 sampai $160{ }^{\circ} \mathrm{C}$ gula (terutama sirup glukosa) mulai mengalami karamelisasi.
Hal ini didukung pula oleh Jackson (1995) yang menyatakan bahwa pada pembuatan Hard Candy dengan metode open pan, larutan gula dipanaskan sampai suhu sekitar $156{ }^{\circ} \mathrm{C}$ dan jika dipanaskan lagi maka akan menyebabkan terjadinya perubahan warna.

Larutan gula yang digunakan sebagai bahan baku utama pembuatan Hard Candy dengan pemanasan suhu tinggi akan mengeras dan mengalami penurunan kadar air. Hal ini sesuai dengan Winarno (2004), bila larutan sukrosa diuapkan maka konsentrasinya akan meningkat, demikian juga dengan titik didihnya. Keadaan ini akan terus berlangsung sehingga air menguap semua dan keseluruhan larutan merupakan cairan sukrosa yang lebur.

\section{Kadar Abu}

Salah satu syarat mutu yang penting untuk permen adalah kadar abu. Kadar abu yang dihasilkan dari produk yang terpilih dalam penelitian ini adalah 0,02\%. Nilai kadar abu yang disyaratkan dalam SNI yaitu maksimal 2,0\%. Dengan melihat data produk terpilih hasil penelitian, perlakuan F1B3 (formula sukrosa 80 gram + air 100 gram + fikosianin 3 gram) memenuhi syarat SNI. Nilai kadar abu kurang dari 2,0\% dapat disebabkan karena bahan yang digunakan (air, sukrosa, glukosa, fikosianin) memiliki tingkat kemurnian yang tinggi.

\section{Kadar Protein}

Protein yang terkandung dalam ekstrak fikosianin yang digunakan dalam pembuatan Hard Candy merupakan protein yang berasosiasi dengan biopigmen fikosianin (fikobiliprotein). Fikobiliprotein adalah jenis protein yang memiliki warna cerah dan bersifat sangat fluorosens (Mailani, 2016). Pigmen fikosianin merupakan kelompok pigmen fikobiliprotein yang dipisahkan menjadi dua kelompok utama berdasarkan warnanya. Kelompok pertama adalah fikoeritrin, yaitu pigmen berwarna merah 
bila terkena cahaya dan memancarkan cahaya pendar berwarna kuning-oranye. Kelompok kedua adalah fikosianin, yaitu pigmen berwarna biru dan memancarkan cahaya pendar merah kuat (Carra et al. 1976).

Kandungan protein yang terkandung dalam formula Hard Candy terpilih (F1B3) yaitu sebesar 72,33 ppm, dianalisis dengan menggunakan metode Bradford. Protein menjadi nilai tambah pada Hard Candy dengan penambahan ekstrak fikosianin karena menambah nilai gizinya dibandingkan dengan hard candy di pasaran.

\section{Stabilitas Warna}

Formula Hard Candy terpilih diuji stabilitas warnanya menggunakan spektrofotometer dengan mengukur intensitas warna biru (absorbansi) pada panjang gelombang $615 \mathrm{~nm}$ (panjang gelombang serapan spesifik dari biopigmen biru fikosianin). Pengamatan stabilitas warna Hard Candy dilakukan selama 28 hari. Berikut merupakan ratarata pengamatan nilai absorbansi Hard Candy formula terpilih F1B3:

Tabel 4. Rata-Rata Nilai Absorbansi

\begin{tabular}{cc}
\hline Hari ke & Absorbansi $(\lambda=615 \mathrm{~nm})$ \\
\hline 0 & $1,107^{\mathrm{a}}$ \\
7 & $1,114^{\mathrm{a}}$ \\
14 & $1,107^{\mathrm{a}}$ \\
21 & $1,112^{\mathrm{a}}$ \\
28 & $1,124^{\mathrm{a}}$ \\
\hline
\end{tabular}

Berdasarkan uji-t dependen (berpasangan) terhadap nilai absorbansi sampel pada hari ke-0 hingga hari ke-28 diperoleh hasil tidak berbeda nyata $(p>\alpha)$ atau nilai absorbansi sampel dari hari ke-0 hingga hari ke-28 stabil.

\section{KESIMPULAN}

Formula Hard Candy terpilih berdasarkan uji hedonik adalah perlakuan F1B3 (formula 80 gram sukrosa +100 gram air $+25 \%$ glukosa $+1 \%$ perisa mint + 3 gram fikosianin) dengan nilai rata-rata tingkat kesukaan panelis terhadap parameter warna 6,16 (suka), rasa 5,44 (agak suka), dan tekstur 5,04 (agak suka).

Berdasarkan hasil uji kimia diperoleh nilai rata-rata kadar gula reduksi Hard Candy adalah 16,92\%, sesuai standar SNI Hard Candy yaitu maksimal 22\%. Rata-rata kadar sakarosa adalah 44,33\%, sesuai standar SNI Hard Candy yaitu minimal 40\%. Rata-rata kadar air adalah 0,92\%, sesuai standar SNI Hard Candy yaitu maksimal 3,5\%. Rata-rata kadar abu adalah 0,02\%, sesuai standar SNI Hard Candy yaitu maksimal 2,0\%. Aktivitas antioksidan ( $\mathrm{IC}_{50}$ ) Hard Candy yaitu 319,06 ppm dan kadar protein Hard Candy yaitu 72,33 ppm. Pada analisis stabilitas warna Hard Candy formula terpilih diperoleh hasil yaitu warna stabil hingga penyimpanan hari ke-28 (warna biru Hard Candy tetap stabil selama 28 hari pengamatan).

\section{DAFTAR PUSTAKA}

Alikonis JJ. 1979. Candy Technology. AVI Publishing Company, Inc., Wesport, Connecticut.

Anonim. 1988. SK Menteri Kesehatan RI Nomor 722/Menkes/Per/IX/88 tentang bahan tambahan pangan. Jakarta: Menteri Kesehatan Republik Indonesia.

Anonim. 2008. Kembang Gula - Bagian 1 : Keras SNI 3547.1:2008. Jakarta: Badan Standardisasi Nasional.

Apriadji, Wied Harry. 2008. Beauty Salad: 8 Salad Buah dan Sayur Cita Rasa Indonesia untuk Tampil Cantik, Langsing, dan Awet Muda. Jakarta: Gramedia Pustaka Utama.

Buckle, K.A., R. A. Edwards, G. H. Fleet and M. Wootton, 1987. Ilmu Pangan. Terjemahan H. Purnomo dan Adiono. UI-Press, Jakarta.

Cahyadi, W. 2006. Analisis dan Aspek Kesehatan Bahan Tambahan Pangan. Jakarta: Bumi Aksara.

Carra and Heocha. 1976. The photosynthetic pigments In: Margalith 
P.Z. (ed.) Pigment Microbiology, Cambridge, England: 84-88.

Hartanti, Amna dan Sri Mulyani. 2009.

Pengaruh Preparasi Bahan Baku

Rosella dan Waktu Pemasakan

Terhadap Aktivitas Antioksidan

Sirup Bunga Rosella (Hisbiscus

sabdariffa L.). Jurnal Argotekno

Vol.15 No,1 : 20-24. Bali: Jurusan

Teknologi Industri Pertanian,

Fakultas Teknologi Pertanian,

Universitas Udayana.

Hidayatulloh, Syarif. 2016. Ekstraksi

Fikosianin dari Spirulina platensis sebagai Biopigmen dan Antioksidan. Bogor: Universitas Djuanda Bogor.

Jackson, EB. 1995. Sugar Convectionery Manufacture. London: Blackie Academic and Professional.

Kawaroe, Mujizat. 2015. Bioenergi dari Alga Laut. Bogor: IPB Press.

Kurnia, Tri Ramadhi. 2009. Pembuatan Hard Candy dengan Penambahan Ekstrak Kelopak Bunga Rosella (Hibiscus sabdariffa Linn). Bogor: Universitas Djuanda Bogor.

Lazuardi, Ruth Arni. 2014. Studi Kestabilan Pewarna Bubuk Alami Fikosianin dari Spirulina sp. Terhadap Cahaya Lampu. Semarang: Universitas Katolik Soegijapranata.

Liputan6. 2013. Zat Warna Biru pada Makanan Paling Berbahaya Bagi Kesehatan.

http://www.liputan6.com/health/re ad/490812/zat-warna-biru-padamakanan-paling-berbahaya-bagikesehatan. Diakses pada 30 Januari 2017 pukul 21.53.

Mailani, Intan. 2016. Penentuan Aktivitas Antioksidan Fikobiliprotein dari Oscillatoria sp.

Merdekawati W, Susanto AB. 2009. Kandungan dan komposisi pigmen rumput laut serta potensinya untuk kesehatan. Squalen 4 (2): 41-47.

Molyneux P. 2004. The use of stable free radical diphenylpicrylhydrazyl (DPPH) for estimating antioxidant activity. Journal of Science Technology 26: 211219.

Mudjajanto, E. S. 2006. Pewarna Makanan. Bogor: Institut Pertanian Bogor (Departemen Gizi Masyarakat dan Sumber Daya Keluarga, Fakultas Pertanian).

Pirenantyo P dan Limantara L. 2008. Pigmen senyawa Spirulina sebagai senyawa anti kanker. Indonesia Journal of Cancer (4): 155 - 163.

Srihari et al. 2010. Pengaruh Penambahan Maltodekstrin pada Pembuatan Santan Kelapa Bubuk. Semarang: Universitas Diponegoro.

Winarno, F.G. 2004. Kimia Pangan dan Gizi. Jakarta: PT Gramedia Pustaka Utama. 